\title{
ADNEXAL SKIN TUMORS IN ZARIA, NIGERIA
}

\author{
M. O. A. Samaila
}

Department of Pathology, Ahmadu Bello University Teaching Hospital Shika -Zaria, Nigeria

Reprint request to: Dr. M. O. A. Samaila, Department of Pathology, A. B. U.Teaching Hospital, Shika-Zaria, Nigeria. Email: mamak97@yahoo.com Tel: +234 8035891007

\begin{abstract}
Background: Adnexal skin tumors share many features in common and differentiate along one line. Their detailed morphological classification is difficult because of the variety of tissue elements and patterns seen. They may be clinically confused with other cutaneous tumors. The aim of this report is to review and classify all adnexal tumors seen in a pathology department over a 16year period.

Method: A 16-year retrospective analysis of all adnexal skin tumors seen in a large University Teaching Hospital in Nigeria from January 1991- December 2006. All tissue specimens were fixed in $10 \%$ formalin, processed in paraffin wax and stained with Haematoxylin and Eosin. Histology slides were retrieved, studied and lesions characterized.

Results: Fifty-two adnexal tumors were seen, accounting for $0.9 \%$ of all cutaneous tumors seen within the same period. The median age was 33years (range: 4days -70years). Clinical presentations varied from discreet swellings and nodules to ulcerated masses. Five patients presented with recurrent lesions. Only two cases had a clinical diagnosis of adnexal tumor. Twenty-four (46\%) of the lesions were distributed in the head and neck region. Duration of symptoms was 2 months to $15 y e a r s$ (median: 12 months). Tumours of the sweat gland were the commonest- $41(78.8 \%)$; they comprised predominantly eccrine acrospiroma(17), characterized histologically by solid nests of round to polygonal cells with clear to eosinophilic cytoplasm, forming tubules in areas. Tumours of sebaceous gland were 7 (13.5\%); they comprised mainly Nevus sebaceous of Jadassohn (6), composed of immature sebaceous glands and pilar structures microscopically and a solitary sebaceous adenoma. Tumours of hair follicle were 4 (7.7\%) and included trichoepithelioma, characterized microscopically by multiple horn cysts and epithelial tracts connecting abortive pilar structures and a trichofolliculoma. Forty-six lesions (88.5\%) were benign and six (11.5\%) malignant.

Conclusion: Adnexal skin tumors have distinct histological patterns which differentiates them from other cutaneous tumors. They are commonly distributed in the head, neck and trunk. The commonest variants are those of eccrine sweat gland origin. Malignant adnexal tumors are uncommon in our setting.
\end{abstract}

Key Words: Adnexal tumours, ecrine sweat gland

\footnotetext{
Résumé

Introduction: Adnezal tumeurs de la peau partagent pas mal de traits caractéristiques en commun et il y a des différences le long d'une ligne. Leur fiche de classification morphologique est difficile en raison de la variété des éléments des tissus et des tendances vues. Elles peuvent être cliniquement confondue avec d'autres tumeurs cutanées. L'objet de ce rapport est de passer en revue et de classifier tous les adnexal tumeurs vues dans un département de pathologie au cours d'une durée de 16 ans.

Méthodes: Une analyse rétrospective d'une durée de 16 ans de l'assemble des tumeurs de la peau adnexal vues dans un grand centre hospitalier universitaire au Nigéria depuis janvier 1991 décembre2006. Tous les spécimens des tissus ont été fixés dans un formol $10 \%$, traité dans une paraffine solide et teintée avec I'hématoxyline et l'Eosine. Des plaques histologiques ont été retrouvées, étudiées, et les lésions caractérisées.
} 
Résultats: Cinquante deux adnexal tumeurs ont été observées, ce qui représente 0,9\% des tumeurs cutanées vues au cours de cette période. L'^âge médian était de 33 ans (groupe d’âge de 4 jours au 70 ans. Des présentations cliniques varient de gonflements et de nodules discret et des nodules aux masses ulcéreuses. Cinq patients présentaient des lésions récurrentes. Deux cas seulement ont eu un diagnostic clinique de adnexal tumeur. Vingt-quatre soit $46 \%$ des lésions ont été distribuées dans la région de la tête et du cou. La durée des symptômes était de 2 mois à 15 ans (médians: 12 mois). Tumeurs de la glande sudoripare sont les plus communs. 41 soit $78.8 \%$, ils comprenaient essentiellement encrine acrospirome (17), caractérisée histologiquement par de solides nids de round à polygonal cellules claires à cosonophilic cytoplasme, formant des tubes dans les régions. Tumeurs des glandes sébacées étaient 7 soit 13.5\%, ils comprenaient surtout de Nevus sébacées de Jadassohn (6), composé de glandes sébacées et immaturés structures de pilier au microscope et d'un adénome solitaire sébacées. Tumeurs du follicule pileux étaient 4 soit 7,7\% et inclus trichoepitheliome, caractérisée microscopique ment par horn multiple kystes et appareil épithéliaux reliant des structures des piliers avortés et un une trichofolliculome. Quarante six lésions soit $88,5 \%$ sont bénignes et six soit $11,5 \%$ malignes.

Conclusion: Adnexal tumeurs de la peau ont des schémas histologiques qui les différencie des autres tumeurs cutanées. Le plus souvent, ils sont distribués dans la tête, du cou et du tronc. Parmi les variantes sont celles des glandes sudoripares ecerine d'origine Adnexal tumeurs malignes sont rares dans notre milieu.

Mots clés: Adnexal tumeurs, eccrine glandes sudoripares

\section{Introduction}

The adnexae is part of the epidermis of the skin and is composed of different kinds of cells that can give rise to a wide variety of tumors. ${ }^{1-3}$ It is comprised of sweat glands, sebaceous glands and hair follicles, all of which share the same origin. Thus tumors arising from them share many features. ${ }^{1}$ Any detailed morphological classification of these tumors run into difficulties owing to the variety of tissue elements and patterns seen. The majority of these tumors are benign and are rarely malignant. ${ }^{4}$ This is a report of the histological patterns of adnexal tumors seen in a $16 y e a r$ period.

\section{Materials and Methods}

All histologically diagnosed adnexal tumors at the department of Pathology, Ahmadu Bello University Teaching Hospital Zaria, Nigeria from January 1991 to December 2006 were reviewed. The tissue specimens were received and fixed in $10 \%$ formalin and were processed in paraffin wax. Histology sections stained with routine Haematoxylin \& Eosin (H\&E) were retrieved and reviewed by the authors. Special stains such as periodic acid schiff [PAS], Van Gieson and Alcian blue were employed where required.

The biodata, clinical history and anatomical sites of lesions were obtained from patients' accompanying case cards. The tumors were grouped based on adnexae origin.

The most reliable histopathologic criteria for identifying malignant adnexal tumors are decapitation secretion, periodic acid schiff positive diastase resistant material in the cells and immunoreactivity with gross cystic disease fluid protein 15.

\section{Results}

There were 52 adnexal tumors. During the same period, a total of 5642 cutaneous tumors were seen. There were 26 males and females each, aged 4days to 70years (median -33years). Two-peak age distributions (0-20years and 40-50years) were noted (Table 1).

Duration of symptoms was from birth to $15 y$ years (median 12months). Clinical presentations included discreet swellings (15), nodules (23), hypertrophic surgical scar (1), polyps (6), ulcerations (3) and fungating masses (4). Five patients presented with recurrent lesions. Range of clinical diagnoses included pyogenic granuloma $4(7.7 \%)$, papilloma 6 (11.5\%), naevus 2 (3.8\%), lipoma 3 (5.8\%), hypertrophic scar 1 (1.9\%), skin nodule 2 (3.8\%), foreign body granuloma 1 (1.9\%) molluscum contagiosum 2 (3.8\%), chronic osteomyelitis 1 (1.9\%), hematoma $1(1.9 \%)$, fibroma $8(15.4 \%)$, cysts 5 (9.6\%), liposarcoma 1 (1.9\%), rhabdomyosarcoma 1 (1.9\%), malignant melanoma 6 (11.5\%) and squamous cell carcinoma 6 (11.5\%). Only two cases had a clinical diagnosis of syringoma. There was no positive family history of similar lesions in any of these patients.

Tumors were categorized on adnexea origin: Sweat gland 41 (78.8\%), sebaceous gland 7 (13.5\%) and hair follicle 4 (7.7\%). Forty-six (88.5\%) were benign and six (11.5\%) malignant (Table 2$)$. 
Table 1. Distribution of 52 tumor and age

\begin{tabular}{|c|c|c|c|c|c|}
\hline Tumour Type & $0-19$ & $20-39$ & $40-59$ & $60+$ & Total (\%) \\
\hline \multicolumn{6}{|l|}{ Benign } \\
\hline \multicolumn{6}{|l|}{ Eccrine sweat gland } \\
\hline Eccrine poroma & 2 & 4 & - & - & $6(11.5)$ \\
\hline Eccrine acrospiroma & 5 & 3 & 8 & 1 & $17(32.7)$ \\
\hline Syringoma & 2 & 2 & - & 1 & $5(9.6)$ \\
\hline Papillary syringoadenoma & 1 & - & 1 & - & $2(3.8)$ \\
\hline Eccrine dermal cylindroma & - & 2 & 3 & - & $5(9.6)$ \\
\hline \multicolumn{6}{|l|}{ Sebaceous gland } \\
\hline Nevus sebaceus of Jadassohn & 4 & 2 & - & - & $6(11.5)$ \\
\hline Sebaceous adenoma & - & - & 1 & - & $1(2.0)$ \\
\hline \multicolumn{6}{|l|}{ Hair follicle } \\
\hline Trichoepithelioma & 2 & - & - & 1 & $3(5.8)$ \\
\hline Trichofolliculoma & 1 & - & - & - & $1(2.0)$ \\
\hline \multicolumn{6}{|l|}{ Malignant } \\
\hline Sweat gland carcinoma & - & 1 & 4 & 1 & $6(11.5)$ \\
\hline Total & 17 & 14 & 17 & 4 & $52(100)$ \\
\hline
\end{tabular}

\section{Sweat gland}

Benign sweat gland tumors comprised: eccrine acrospiroma 17 (32.7\%), eccrine poroma 6 (11.5\%), syringoma 5 (9.6\%), eccrine dermal cylindroma 5 (9.6\%) and papillary syringoadenoma 2 (3.8\%). Eccrine acrospiroma was characterized histologically by solid nests of round to polygonal cells with clear to eosinophilic cytoplasm, forming tubules in areas (Figure 1). Distribution was mainly in the trunk and extremities. All five dermal cylindroma were confined to the scalp and microscopy showed tumor lobules composed of epithelial cell nests separated by hyaline material in a loose stroma. Malignant variant comprised eccrine sweat gland carcinoma $(6 ; 11.5 \%)$ composed histologically of solid nests of large oval to spindle to polygonal epithelial cells forming occasional tubule containing eosinophilic globules and separated by fibrous septa (Figure 2).

\section{Sebaceous gland}

The sebaceous tumors comprised mainly a solitary sebaceous adenoma and six cases of nevus sebaceous of Jadassohn (NSJ). The NSJ showed immature sebaceous glands and pilar structures microscopically.

\section{Hair follicle}

Tumours of hair follicle included trichoepithelioma (3; $5.8 \%$ ), characterized microscopically by multiple horn cysts and epithelial tracts connecting abortive pilar structures and a trichofolliculoma $(1 ; 2 \%)$.

Twenty-four (46.2\%) cases were distributed between the scalp, face and neck, while 15 (28.8\%) were distributed on the trunk. The trunk was also the commonest site for the malignant tumors. All sebaceous gland lesions were on the face (Table 3 ).

Table 2. Distribution by of 52 tumors and sex

\begin{tabular}{llll}
\hline Tumour Type & Male & Female & Total (\%) \\
\hline Benign & & & \\
$\quad$ Eccrine sweat gland & & & $6(11.5)$ \\
$\quad$ Eccrine poroma & 2 & 4 & $17(32.7)$ \\
$\quad$ Eccrine acrospiroma & 8 & 9 & $5(9.6)$ \\
$\quad$ Syringoma & 3 & 2 & $2(3.8)$ \\
$\quad$ Papillary syringadenoma & 1 & 1 & $5(9.6)$ \\
$\quad$ Eccrine dermal cylindroma & 1 & 4 & $6(11.5)$ \\
$\quad$ Sebaceous gland & & $1(2.0)$ \\
$\quad$ Nevus sebaceus of Jadassohn & 4 & $3(5.8)$ \\
$\quad$ Sebaceous adenoma & 1 & - & $1(2.0)$ \\
$\quad$ Hair Follicle & & & $6(11.5)$ \\
$\quad$ Trichoepithelioma & 2 & 1 & $52(100)$ \\
Trichofolliculoma & 2 & 1 & 2 \\
$\quad$ Sweat gland carcinoma & - & 26 & \\
\hline Total $\quad$ & 4 & 26 & \\
\hline
\end{tabular}


Table 3. Anatomical site of 53 tumors

\begin{tabular}{|c|c|c|c|c|}
\hline Tumour Type & Head & Trunk & Extremities & Total (\%) \\
\hline \multicolumn{5}{|l|}{ Benign } \\
\hline \multicolumn{5}{|l|}{ Eccrine sweat gland } \\
\hline Eccrine poroma & 1 & 1 & 4 & $6(11.5)$ \\
\hline Eccrine acrospiroma & 4 & 6 & 7 & $17(32.7)$ \\
\hline Syringoma & 2 & 2 & 1 & $5(9.6)$ \\
\hline Papillary syringoadenoma & 2 & - & - & $2(3.8)$ \\
\hline Eccrine dermal cylindroma & 4 & 1 & - & $5(9.6)$ \\
\hline \multicolumn{5}{|l|}{ Sebaceous gland } \\
\hline Nevus sebaceus of Jadassohn & 6 & - & - & $6(11.5)$ \\
\hline Sebaceous adenoma & 1 & - & - & $1(2.0)$ \\
\hline Trichoepithelioma & 3 & - & - & $3(5.8)$ \\
\hline Trichofolliculoma & 1 & - & - & $1(2.0)$ \\
\hline Hair follicle & - & - & - & - \\
\hline \multicolumn{5}{|l|}{ Malignant } \\
\hline Sweat gland carcinoma & - & 5 & 1 & $6(11.5)$ \\
\hline Total & 24 & 15 & 13 & $52(100)$ \\
\hline
\end{tabular}

Figure 1. Eccrine acrospiroma forming tubules in areas (H \& E x 100)

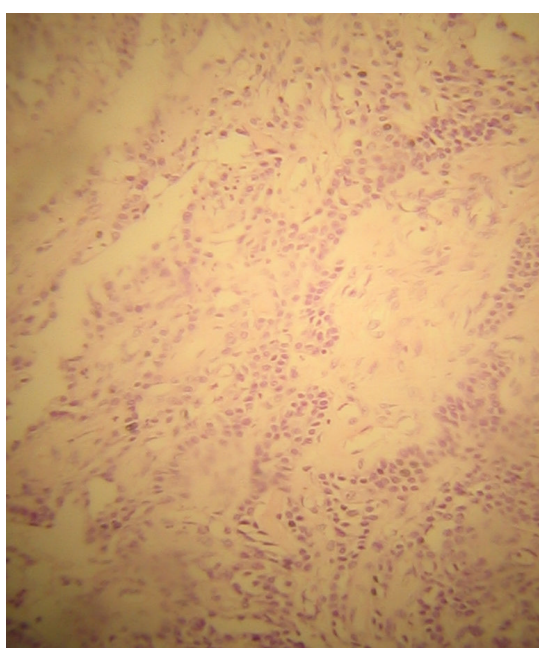

Figure 2. Sweat gland carcinoma; nests of polygonal cells forming occasional tubule and separated by fibrous septa. (H \& E x 100)

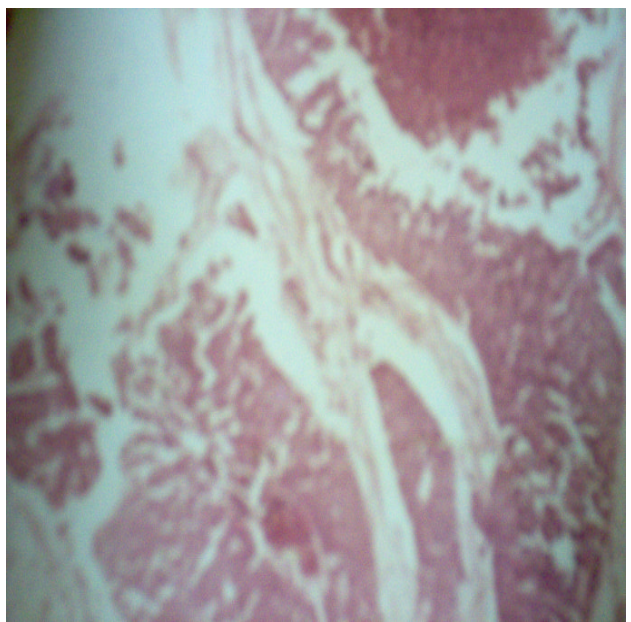

\section{Discussion}

Skin adnexal tumors constitute a small percentage of cutaneous tumors in our environment. They formed $0.9 \%$ of all cutaneous neoplasms seen in the Department during the study period emphasizing their rarity. ${ }^{2}$ No reliable data exist on the racial and geographic incidence of these tumors. Their causation is not well understood; however, the large majority differentiates along one adnexeal line. ${ }^{1,2}$

The sweat gland tumors were the largest group encountered in this study (78.8\%). The complex nature of the sweat gland may be responsible for this wide array of tumors. ${ }^{1}$ Eccrine acrospiroma (hidradenoma) was in the majority with a wide age distribution from first to seventh decade and insignificant sex difference. The cases were distributed in nearly all the sites including hand, face, upper and lower limbs. The morphologic appearance was predominantly solid nests composed of round cells with dark nuclei and clear cytoplasm confined to the dermis, findings similar to other reports. ${ }^{2,5}$

Nevus sebaceous of Jadassohn is not neoplastic rather a tumor like lesion because of its harmatomatous conglomerate of sebaceous glands and heterotropic apocrine glands and defective hair follicle. ${ }^{1-4}$ The tumors of hair follicle, like those of sweat gland, have varying histological features than in their clinical features. ${ }^{2}$ The three cases of trichoepitheloma occurred as solitary tumors in the face, scalp and neck. None of the patients gave a positive family history. Solitary trichoepitheliomas, which are non-familial, may cause difficulty and are sometimes difficult to distinguish from a basal cell carcinoma. This confusion is understandable because of the linear differentiation of these tumors. ${ }^{1,2}$

Malignant adnexal tumors are rare world wide. ${ }^{4}$ The six cases encountered in the present report 
occurred predominantly in the trunk with a higher male frequency. One report noted the axilla as the preferred site. ${ }^{6}$ They represented $11.5 \%$ of the 52 tumors reviewed, further emphasizing their rarity. Malignant appendage tumors were the least common in one report, ${ }^{7}$ with four cases confined to the scalp and trunk and accounting for $3.3 \%$ of total tumors analyzed, and $2.3 \%$ in another report. ${ }^{8}$ Adnexal skin tumors have distinct histological patterns which differentiates them from other cutaneous tumors. They are commonly distributed in the head, neck and trunk. The commonest are benign variants from eccrine sweat gland origin and the malignant tumors are uncommon in our setting.

\section{References}

1. Rosai J. Skin Tumours and Tumour like conditions In: Ackerman's Surgical Pathology. Mosby, St. Louis, 1996; 106-108.

2. Klein W, Chan E, Seykora JT. Tumours of the epidermal appendages. In: Elder DE, Elenitsas R, Johnson BL Jr, Murphy GF (eds). Lever's histopathology of the skin.Lippincott, Williams \& Wilkins, Philadelphia. 2005; 867- 914.

3. Seldam REJ, Helwig EB, Sobin LH, Torloni H. In: Histological typing of skin tumours. International histological classification of skin tumours no 12 . World Health Organization, Geneva. 1974.

4. Cooper P.H. Carcinoma of sweat gland. Pathol Ann1987; 22 (PE 1): 83-124.

5. Janota I. Adnexal skin tumours in Nigeria. $\mathrm{Br} \mathrm{J}$ Dermatol. 1967;79:259-270.

6. Paties C, Taccagni $\mathrm{Cl}$, Papotti M, Valente G, Zangrandi A, Aloi F. Apocrine carcinoma of the skin. A clinicopathologic, immunocytochemical and ultrastructural study. Cancer. 1993;7:375381.

7. Adeyi O, Banjo A. Malignant tumours of the skin: A 6-year review of histologically diagnosed cases [1990-1995]. Nigerian Quarterly Journal of Hospital Medicine. 1998;8:99-102.

8. Mandong BM, Orkar KS, Sule AZ, Dakum NL. Malignant skin tumours in Jos University Teaching Hospital, Jos. Nigeria Journal of Surgical Research. 2001;3:29-33. 